
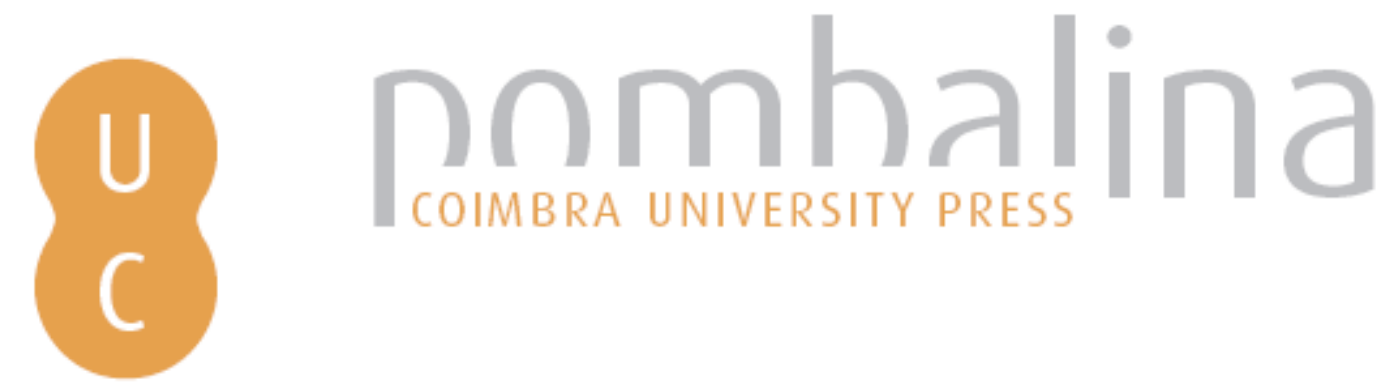

\title{
O poder dos bens deste mundo: um exercício de indagação sobre o testamento seiscentista de João de Mattos de Aguiar
}

\author{
Autor(es): $\quad$ Gandelman, Luciana \\ Publicado por: Imprensa da Universidade de Coimbra \\ URL \\ persistente: URI:http://hdl.handle.net/10316.2/31591 \\ DOI: $\quad$ DOI:http://dx.doi.org/10.14195/978-989-26-0201-1_12 \\ Accessed : $\quad$ 26-Apr-2023 09:48:07
}

A navegação consulta e descarregamento dos títulos inseridos nas Bibliotecas Digitais UC Digitalis, UC Pombalina e UC Impactum, pressupõem a aceitação plena e sem reservas dos Termos e Condições de Uso destas Bibliotecas Digitais, disponíveis em https://digitalis.uc.pt/pt-pt/termos.

Conforme exposto nos referidos Termos e Condições de Uso, o descarregamento de títulos de acesso restrito requer uma licença válida de autorização devendo o utilizador aceder ao(s) documento(s) a partir de um endereço de IP da instituição detentora da supramencionada licença.

Ao utilizador é apenas permitido o descarregamento para uso pessoal, pelo que o emprego do(s) título(s) descarregado(s) para outro fim, designadamente comercial, carece de autorização do respetivo autor ou editor da obra.

Na medida em que todas as obras da UC Digitalis se encontram protegidas pelo Código do Direito de Autor e Direitos Conexos e demais legislação aplicável, toda a cópia, parcial ou total, deste documento, nos casos em que é legalmente admitida, deverá conter ou fazer-se acompanhar por este aviso.

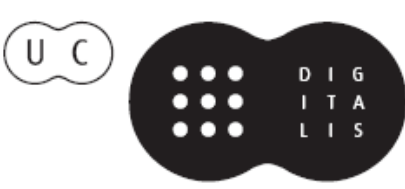


Isabel dos Guimarães Sá Máximo García Fernández (directores)

\section{PORTAS ADENTRO comer, vestir, habitar} (ss. XVI-XIX) 


\title{
O PODER DOS BENS DESTE MUNDO: UM EXERCÍCIO DE INDAGAÇÃO SOBRE O TESTAMENTO SEISCENTISTA DE JOÃO DE MATTOS DE AGUIAR
}

\author{
LUCIANA GANDELMAN \\ Universidad Federal \\ Rural do Rio de Janeiro ${ }^{1}$
}

INCONSTÂNCIA DOS BENS DO MUNDO

Nasce o Sol, e não dura mais que um dia, Depois da Luz se segue a noite escura, Em tristes sombras morre a formosura, Em contínuas tristezas a alegria. Porém, se acaba o Sol, por que nascia? Se é tão formosa a Luz, por que não dura? Como a beleza assim se transfigura? Como o gosto da pena assim se fia? Mas no Sol, e na Luz falte a firmeza, Na formosura não se dê constância, E na alegria sinta-se tristeza. Começa o mundo enfim pela ignorância, E tem qualquer dos bens por natureza A firmeza somente na inconstância ${ }^{2}$.

${ }^{1} \mathrm{O}$ presente texto foi elaborado no âmbito das atividades de pós-doutoramento financiadas pela FAPESP e supervisionadas pela professora dra. Laura de Mello e Souza na Universidade de S. Paulo, no âmbito da Cátedra Jaime Cortesão. A autora gostaria de agradecer igualmente à FCT, pelo auxílio destinado ao projeto «Portas adentro», coordenado por Isabel dos Guimarães Sá, do qual esta pesquisa igualmente faz parte.

${ }^{2}$ Gregório de Matos e Guerra, «Moraliza o poeta nos ocidentes do sol a inconstância dos bens do mundo». Poema disponível em domínio público no site da Universidade Federal da Bahia. http://www2.ufba.br/ gmg/moraliza.html. Visualização: 29 de junho de 2009. 
Constância, inconstância; corrupção, incorruptibilidade; firmeza, mutação. Nos versos atribuídos a Gregório de Matos e Guerra encontramos alguns dos dilemas que envolviam o mundo material para os homens do século XVII. Como afirma João Adolfo Hansen, no cerne das representações teológico-políticas do universo luso-brasileiro seiscentista encontrava-se a oposição complementar finito/infinito, funcionando como uma sindérese, no sentido aristotélico-tomista ${ }^{3}$. Podemos associar a este «primeiro princípio» um desenvolvimento em outros pares de opostos que ajudam a estruturar esta noção de mundo material e, conseqüentemente, bens materiais. Entre eles os já mencionados, constância, inconstância; corrupção, incorruptível, mas também a própria oposição: corpo versus alma, eterno versus perecível; e seus demais desdobramentos hierárquicos: alto versus baixo; católico versus gentio, discreto versus vulgar e fidalgo versus plebeu, que Hansen encontra nos princípios éticos e teológico-políticos da «política católica» seiscentista. Sendo os primeiros sempre princípios eufóricos e os segundos, disfóricos. É neste sentido, que o poeta afirma pela finitude (corruptibilidade e inconstância) dos bens deste mundo em oposição, sempre complementar, aos bens da alma e tudo o que diz respeito ao eterno e ao Eterno.

No exercício de interpretação que proponho devemos ter em mente esses mesmos «primeiros princípios». Se acatarmos a sugestão de José César das Neves, devemos considerar que o modelo aristotélico da riqueza a dividia em dois tipos: «riqueza natural» e «riqueza artificial», separadas de acordo com as necessidades vitais e tudo aquilo que as transcendia, inclusive o dinheiro, e classificava os bens de maneira tripartida: 1) bens externos; 2) bens da alma; 3) bens do corpo ${ }^{4}$. Sendo que a ultrapassagem do que era considerado o «limite natural», geralmente relativo aos bens externos, era visto como moralmente condenável e serviu como base para interpretações aristotélicas acerca dos abusos do comércio e dos lucros.

A influência das idéias de Aristóteles acerca da riqueza no pensamento da escolástica e nos debates trazidos pelas ordens mendicantes já foi longamente explorada por historiadores e filósofos ${ }^{5}$. Para Neves, o pensamento de Tomás de Aquino teria aceitado e se utilizado da tipologia aristotélica da riqueza em seus trechos mais clássicos, porém a teria rejeitado ou, ao menos, a reconsiderado em passagens menos conhecidas. É certo que Tomás de Aquino tenha feito reconsiderações em relação ao comércio, por exemplo, respeitando o contexto de seu crescimento e maior importância na época medieval. Além disso, é igualmente

${ }^{3}$ João Adolfo Hansen. A sátira e o engenho: Gregório de Matos e a Bahia do século XVII. São Paulo: Ateliê Editorial, Campinas, Editora da Unicamp, 2004, p. 26.

${ }^{4}$ José César das Neves. «Aquinas and Aristotle`s distinction on wealth», History of Political Economy, vol. 32, 2000, n. 3, pp. 649-650.

${ }^{5}$ Ver, entre outros: John T. Noonan, The Scholastic Analysis on Usury. Cambridge, Harvard University Press, 1957 e R. De Roover, La pensée économique des scholastiques, doctrines et methodes, Montréal/ Paris, Vrin, 1971. 
importante termos em mente que o pensamento aristotélico-tomista foi alvo de intenso debate nos séculos XVI e XVII, especialmente em seus desdobramentos com relação às concepções de dinheiro e de usura, e que os participantes da chamada «segunda escolástica», como aqueles pertencentes à Escola de Salamanca e seus discípulos, desenvolveram, em vários aspectos, as considerações aristotélicas acerca da infertilidade do dinheiro e da imoralidade dos juros.

Esta discussão é extremamente complexa e não cabe neste espaço levá-la mais a fundo. No entanto, acredito ser correto afirmar que, para boa parte dos moralistas e tratadistas católicos portugueses esses «primeiros princípios» com relação à riqueza mantêm-se verdadeiros ou, ao menos, servem de ponto de partida ou contraponto de reflexão. Não é à toa que aparecem expressos nos poemas satíricos seiscentistas de Gregório de Matos. Como consequência, o poeta, em diversos outros poemas, vitupera e condena o apego aos bens materiais e todos seus desregramentos derivados e paixões como a ganância, a cobiça, a avareza, a usura e o apego excessivo à riqueza. Ou seja, de um lado, a usura, a ambição, o negócio, a loucura e a perdição e em seu campo oposto a verdade, a honra, a liberalidade e a vergonha ${ }^{6}$.

Muito se tem discutido acerca das crises e dilemas do século XVII em relação ao mundo material ${ }^{7}$. Daniel Roche sintetizou bem as questões que parecem estar envolvidas ${ }^{8}$. Para o autor, é através da literatura religiosa que podemos compreender melhor como o homem do século XVII entendia as relações entre os homens e as coisas. Recorrendo aos tratadistas franceses, Roche afirma que a sociedade de então não ignorava as riquezas, mas entendia que sua existência deveria ser justificada perante a pobreza daqueles que não a possuíam. Como resultado desta ambigüidade com relação à riqueza material, proliferavam os discursos acerca da futilidade e do engano na busca humana por bens materiais, como podemos ver nos próprios poemas satíricos de Gregório de Matos ou em obras como A arte de furtar ${ }^{9}$. Sendo esta mais uma das paixões e desregramentos humanos, que distanciavam os homens de Deus e suas premissas. Como aqueles que possuíam bens materiais, ou seja, os ricos, deveriam agir neste caso, questiona Roche? E quais deveriam ser as regras de divisão dos bens entre os

${ }^{6}$ João Adolfo Hansen, ob. cit., pp 477-478.

${ }^{7}$ Sobre esta questão nos séculos XVI e XVII ver: Bartolomé Clavero, La Grace du don: anthropologie catholique de l'économie moderne, Paris, Albin Michel, 1996; Daniel Dessert, «O financeiro» In Rosario Villari (org). O homem barroco, Lisboa, Presença, 1995; António Manuel Hespanha. «La economia de la gracia» In La gracia del derecho, Madrid, Centro de Estudios Constitucionales, 1993; Pedro Almeida Cardim, O poder dos afetos: ordem amorosa e dinâmica política no Portugal do Antigo Regime, Lisboa, Tese de doutorado, Universidade Nova de Lisboa, 2000.

${ }^{8}$ Daniel Roche, História das coisas banais: nascimento do consumo, séculos XVII-XIX, Rio de Janeiro, Rocco, 2000, pp. 103-106.

${ }^{9}$ Anónimo, A arte de furtar, São Paulo, L\&PM, s/d. [obra originalmente datada de 1652]. 
homens? Segundo o autor, a divisão dos bens deveria seguir o funcionamento da «sociedade de corpos e estatutos» e da cultura econômica mercantilista, no interior de uma hierarquia dos consumos equivalente à de poderes. Os potentosos deveriam seguir «ao mesmo tempo, a economia moral, que unia a responsabilidade do soberano e dos ricos em relação ao bem público, e a moral da economia, que aconselhava o uso moderado dos bens segundo a classe social ${ }^{1{ }}{ }_{\gg}$. O bom funcionamento da sociedade devia ser mantido pelos mecanismos da troca e do dom $^{11}$. Desta forma, o consumo de luxo podia, portanto, ser transformado em caridade, e consequentemente, em bens espirituais, ou bens das almas, por meio das obras de auxílio à pobreza ${ }^{12}$.

É em meio a esse contexto que propomos uma leitura e algumas indagações acerta dos bens materiais contidos nas últimas vontades expressas pelo testador João de Matos de Aguiar $^{13}$. Os testamentos constituem um campo de exploração da historiografia que possui uma certa especificidade ${ }^{14}$. Este não será, entretanto, o local de fazer uma discussão mais aprofundada do tema, ainda que esta seja mantida no horizonte de análise, pois o objetivo, neste caso, é promover uma discussão específica acerca de seus bens materiais, seus significados e uso.

${ }^{10}$ Daniel Roche, ob. cit., p. 104.

${ }^{11}$ Obras sobre o dom ou dádiva: Marcel Mauss, Sociologia e antropologia, São Paulo, EDUSP, 1974; Natalie Zemon Davis, The gift in Sixteenth-Century France, Madison, The University Of Wisconsin Press, 2000; Bartolomé Clavero, La Grace du don: anthropologie catholique de l'économie moderne, Paris, Albin Michel, 1996; António Manuel Hespanha, «La economia de la gracia» In La gracia del derecho. Madrid, Centro de Estudios Constitucionales, 1993; entre outros.

${ }^{12}$ Sobre a questão ver, entre outros, Isabel dos Guimarães Sá, Quando o rico se faz, pobre: Misericórdias, caridade e poder no império português 1550-1800, Lisboa, Comissão Nacional para as Comemorações dos Descobrimentos Portugueses, 1997; Michel Mollat, Os pobres na Idade Média, Rio de Janeiro, Campus, 1989; Bronislaw Geremek, A piedade e a forca: história da miséria e da caridade na Europa, Lisboa, Terramar, s/d; Lester K Little, Religious poverty and the profit economy in Medieval Europe, Ithaca, Cornell University Press, 1978; Jacques Le Goff, A bolsa e a vida: a usura na Idade Média, São Paulo, Brasiliense, 2004; A. J. R. Russell-Wood, Fidalgos e Filantropos: A Santa Casa da Misericórdia da Bahia, 1550-1755. Brasília, Editora Universidade de Brasília, 1981.

${ }^{13}$ Arquivo Nacional Torre do Tombo, «Habilitação de herança de Cristina Roiz de Matos». Feitos Findos. Juízo da Índia e Mina. Justificações Ultramarinas, Brasil, maço 124, documento 7 , pp. $26 \mathrm{~V}-49$.

14 Sobre a questão da «boa morte» e dos testamentos ver Michel Vovelle. La mort et l'occident: de 1300 à nos jours, Paris, Gallimard, 1983; Jacques Le Goff, O nascimento do purgatório, Lisboa, Estampa, 1995; Philippe Ariès, $O$ homem diante da morte, Rio de Janeiro, F. Alves, 1990, 2 vols.; Idem, História da morte no ocidente: da Idade Média aos nossos dias, Rio de Janeiro, F. Alves, 1977; João José Reis, A morte é uma festa: ritos fúnebres e revolta popular no Brasil do século XIX, São Paulo, Companhia das Letras, 1991; Maria Manuela B. Martins Rodrigues, Morrer no Porto durante a Época Barroca: atitudes e sentimento religioso, dissertação de mestrado, Porto, Faculdade de Letras da Universidade do Porto, 1991; Ana Cristina Bartolomeu de Araújo, A morte em Lisboa: atitudes e representações, 1700-1830, Tese de doutorado, Coimbra, Universidade de Coimbra, 1995. 
Pensando na trilogia material de Aristóteles -bens externos, bens da alma e bens do corpo- não vamos tratar aqui diretamente dos bens das almas, tema que tem ocupado considerável espaço na historiografia, nem discutiremos com atenção a questão do testamento e do ato de testar, embora estas questões sejam de grande importância e estejam constantemente sendo referidas mesmo que indiretamente, uma vez que são preocupações e noções que influem na maneira como os bens materiais são encarados no período, são indissociáveis desta e ajudam a delimitar justamente a definição e as fronteiras desses bens materiais, mesmo quando funcionam como uma espécie de contrário.

Trata-se de inquirir como um homem de grandes cabedais distribuiu a sua fortuna e como considerava seus bens materiais, no momento de sua morte iminente, em finais do século XVII. Uma indagação acerca dos bens e objetos que possuía, como os agrupa e os classifica e como deles dispõe na hora de fazer seu testamento. Algumas advertências se fazem necessárias. Trataremos de seu testamento apenas, pois o inventário dos seus bens, se foi realizado, não chegou até nós ou ao menos não foi localizado até o momento. Isto significa dizer que estaremos investigando a forma como este homem considerava seus bens e como pensou em distribuí-los às vésperas de sua morte. Neste sentido, temos uma visão pessoal desses bens e não teremos, por assim dizer, a avaliação comunitária dos mesmos, realizada quando da elaboração dos inventários, e que poderia nos servir de contraponto. É uma fala que, além de seguir as normas, religiosas e temporais, da escrita testamentária, respeita a memória e as predileções pessoais do testador. Por conseguinte, não é uma descrição exaustiva de seus bens, mas um relato daqueles bens e objetos que ele considerou relevantes o suficiente para serem objeto de detalhamento e transmissão a parentes, amigos e escravos. O peso da oposição material/espiritual torna-se especialmente crítico em um testamento, quando estas questões tornam-se mais prementes.

Isto significa também que temos um retrato de seus bens ao final da construção de sua vida e fortuna, ao longo de 70 anos. Estes são, portanto, bens de um homem já idoso, no final de sua trajetória e não respondem por todos os reveses e pelas transformações pelas quais deve ter passado. É preciso assinalar ainda que são bens de um homem, ou seja, trazem a marca da especificidade de seu gênero no período e que se tratava de um celibatário ${ }^{15}$. Não se deve esquecer igualmente que era um homem nascido em Portugal e que, mesmo vivendo na Bahia o restante de sua vida, manteve ativo contato com o reino. Por não ter herdeiros forçados, a alma de João de Matos tornou-se sua herdeira universal, constituindo-se, por conseguinte, em presença predominante no testamento.

${ }^{15}$ Sobre a relação entre gênero e posse de bens ver Isabel dos Guimarães Sá. «Between spiritual and material culture: male and female objects at the Portuguese Court, 1480-1580» in Sandra Cavallo e Silvia Evangelisti (eds), Domestic Interiors in Early Modern Europe, Aldershot, Ashgate, 2008, pp. 149-176. 
João de Matos de Aguiar faleceu no dia 26 de maio de 1700, na cidade da Bahia de Todos os Santos. Ele havia nascido no norte de Portugal, em 1630, e migrado para a América Portuguesa em meados do século XVII. Veio para a Bahia para ser recebido por um tio, João de Matos, «o velho», como ficaria conhecido. Ao longo de sua trajetória, exerceu diversas funções na governança local, foi irmão e ocupou vários cargos na Misericórdia de Salvador, foi senhor de fazendas de cana na Patatiba e de fazendas de gado no sertão baiano, em Itapicuru, e foi, mais do que isto, um dos maiores credores particulares em seu período.

Tendo ficado sua alma como sua herdeira universal, o provedor e irmãos da mesa da Santa Casa da Misericórdia de Salvador ficaram encarregados como seus testamenteiros. O legado que Matos de Aguiar deixou à Misericórdia possuía muitas características comuns aos testamentos «barrocos» e ditames da «boa morte» no período, como o número volumoso de missas -6.000 missas anuais perpétuas em prol da sua alma- e uma variedade de obras pias, entre elas esmolas aos pobres do hospital da irmandade, dotes para meninas órfãs (honradas, brancas e cristãs-velhas) e a instituição de um recolhimento para mulheres.

A forma de financiamento dessas instituições era igualmente comum ao período. Todos os mencionados legados pela sua alma eram perpétuos, enquanto «o mundo for mundo», e deviam ser financiados pelo emprego dos recursos existentes na forma de empréstimos a juros. O capital dirigido à «capela de missas» totalizava 40:000\$000 réis. O montante destinado às esmolas aos pobres do hospital chegava ao equivalente a 16.000 cruzados $^{16}$, ou 6:400\$000 réis, de cujos rendimentos deveriam gerar esmolas de $1 \$ 000$ réis a cada pobre que saísse do hospital. Os dotes deveriam ser financiados a partir de um principal no valor de 135:470\$280 réis, que deveriam render 38 dotes anuais de 100\$000 réis cada $u^{17}{ }^{17}$. A construção do recolhimento de mulheres deveria ser financiada com um principal de 40:000\$000 réis, com o rendimento anual dos juros, de 2:500\$000 réis ${ }^{18}$. Depois de aberto o recolhimento, os juros deveriam ser utilizados para o sustento da mesma casa e de suas recolhidas.

Como se pode notar, o cabedal de Matos de Aguiar era considerável. O valor total do legado somava algo em torno de 228:000\$000 réis, quantia muito alta que o tornou o maior legatário da irmandade na Bahia ${ }^{19}$. Os outros dois

${ }^{16}$ Equivalência feita a partir dos valores fornecidos por Evaldo Cabral de Mello, $O$ negócio do Brasil: Portugal, os Países Baixos e o Nordeste, 1641-1669, Rio de Janeiro, Topbooks, 2003, p. 20.

${ }^{17}$ Dos 38 dotes, 5 eram financiados com o aluguel de duas fazendas de cana do Recôncavo e algumas casas na cidade e o restante aparentemente resultava do dinheiro posto a juros.

${ }^{18}$ Antônio Joaquim Damazio, Tombamento dos bens imóveis da Santa Casa da Misericórdia da Bahia 1862, Bahia, impressão da irmandade, 1865, p. 153.

${ }^{19}$ Quantia avaliada por Carlos Ott, A Santa Casa da Misericórdia de Salvador, Rio de Janeiro: Patrimônio Histórico e Artístico Nacional, 1960, p. 24. 
maiores legatários da Misericórdia no período foram: Francisco Fernandes do Sim, com 10:600\$000 réis, em 1664, e Domingos Fernandes de Freitas, de 1688, com 18:733\$058 réis ${ }^{20}$. Para termos uma noção das ordens de grandeza envolvidas é interessante lembrarmos que, de acordo com Stuart Schwartz, o valor dos engenhos de açúcar na Bahia e Pernambuco seiscentistas girava em torno de 12 a 20 contos, podendo ser avaliados por 6 a 8 contos, especialmente se não fosse computada a escravaria ${ }^{21}$.

Como João de Matos decidiu então dividir a sua fortuna? Não tendo herdeiros forçados, como dito anteriormente, a sua alma ficou sendo sua herdeira principal. Para a alma vão, portanto, a maior parte de seus «bens de raiz» na forma de legados variados ${ }^{22}$, uma vez que a eternidade de sua existência demanda bens que, ainda que não a possam alcançar, durem ao menos «quanto durar o mundo», a terra e os demais bens corruptíveis da existência humana. E para os homens do período os bens de raiz têm essa durabilidade e, por conseguinte, essa temporalidade que ultrapassa a vida corporal humana individual. Por isso, segundo João de Matos de Aguiar, seus bens de raiz não poderiam jamais ser vendidos. Portanto, para os legados ligados à salvação e encaminhamento de sua alma vão as quatro fazendas de cana na Patatiba e as casas urbanas em Salvador, «estas moradas de $\operatorname{casas}^{23}$ e as da rua Direita», rua das principais da cidade e sede das instituições do poder local, onde João de Matos arrematou uma casa que havia sido de seu tio. Para garantir a longevidade de seus rendimentos tudo devia ser arrendado e alugado. No caso de João de Matos, seus créditos ativos compõem, em verdade, a maior parte de sua fortuna, e representando uma espécie de «renda», parecem manter uma certa vizinhança de caráter, para o testador, com as rendas retiradas das terras e dos aluguéis.

Os bens de raiz são igualmente os bens ligados à família, à «geração» (genus), no sentido de origem e ramo familiar. Ultrapassam a temporalidade individual, menos importante, e alcançam a temporalidade das famílias, da sucessão das gerações e das «casas», como se dizia no período no caso dos nobres. Para a sua família, que havia ficado no norte de Portugal, deixava «encapelados» ${ }^{24}$ seis currais de gado vacum e cavalar com mais de 70 escravos, que ainda trabalha-

${ }^{20}$ Arquivo Histórico da Santa Casa da Misericórdia da Bahia. Livro das instituições, 1623$1773,211 \mathrm{c}$.

${ }^{21}$ Stuart Schwartz, Segredos internos: engenhos e escravos na sociedade colonial, São Paulo: Companhia das Letras, 1988, p. 185.

${ }^{22}$ Bens de raiz equivalem a bens imóveis atualmente.

${ }^{23}$ Casa: «morada de casas, edifício, em que vive uma família com seus móveis e alfaias, amparada das injúrias do tempo». Raphael Bluteau, Vocabulário português e latino, 8 vols, Coimbra, Colégio das Artes da Companhia de Jesus, 1712-1727, vol. 2, p. 172.

${ }^{24}$ Capela: «fazenda que o testador deixa com obrigação de missa. Instituição que vincula certa parte das rendas a encargos de obras pias e etc. e obriga os sucessores e herdeiros à satisfação dos ditos encargos.» Raphael Bluteau, ob. cit., vol. 2, p. 122. 
vam no cultivo do tabaco. Os rendimentos dessa capela deveriam servir para dotar as filhas de suas sobrinhas e de seus sobrinhos e seus respectivos descendentes, enquanto o «mundo fosse mundo». Como define D. Raphael Bluteau, as capelas eram instituições que estabeleciam patrimônios certos, os quais deveriam ser aplicados pelos herdeiros no cumprimentos de obras pias e, mais comumente, na realização de missas. João de Matos, como tantos homens do período, encarava a dotação de moças como enquadrada nessa categoria e chamava suas parentas de «pobres legatárias e sua descendência». Como consequência, rogou a seus sobrinhos administradores que fizessem «cristãmente sua obrigação para suas parentas». Começando com um sobrinho seu, Francisco de Matos de Aguiar, que já se encontrava naqueles sertões, a administração da capela deveria seguir a linha masculina da família, respeitando sempre a preferência dos parentes mais chegados e «verdadeiramente de sua «geração». Até o fim do mundo, portanto, a geração masculina emigrada para a América deveria administrar a capela de dotação da linha feminina, residente no norte do reino de Portugal, garantindo desta maneira a continuidade familiar e o bem da «geração». Para garantir os bons rendimentos e povoar o local os sobrinhos podiam arrendar porções da terra a pessoas interessadas. João de Matos procurou garantir, desta maneira, a reprodução e a manutenção, se não o melhoramento, do estatuto social de sua família, por meio do casamento e de rendimentos vindos de bens de raiz.

Aos sobrinhos que haviam emigrado para a América portuguesa com o intuito de fazerem vida junto ao tio, como ele mesmo havia feito quase quarenta anos antes, deixava, além da administração da capela familiar, quantias em dinheiro para a ajuda nos estudos àqueles que haviam seguido a carreira eclesiástica e jurídica. Ao sobrinho, João de Aguiar de Matos, deixava ainda os serviços prestados a sua majestade, para que deles recebesse mercês, como igualmente havia feito seu tio com ele.

Para o financiamento de seu funeral e enterro, cerimônia efêmera, ainda que não menos importante, uma vez que se destinava tanto ao corpo quanto à alma, ficava reservado tudo o que possuía em ouro e prata. Para combinar com a temporalidade veloz da situação, tudo que se encontrava enquanto objetos, devia ser vendido. Quanto ao dinheiro em espécie, possuía ao redigir seu testamento, em moedas de ouro 38 de quatro mil réis e uma de dois mil réis, que somavam cento e cinqüenta e quatro mil réis. Objetos e dinheiro, por serem do mesmo material e representarem a possibilidade de valor e liquidez imediata, formam, por assim dizer, um mesmo conjunto. Aqui encontramos um flagrante das múltiplas funções e da dubiedade que era atribuída tanto aos objetos de metal precioso, no caso do ouro e da prata, quanto ao próprio dinheiro. Sua materialidade comum e seu valor intercambiável tornavam suas naturezas difusas e o seu emprego variado. Havia, portanto, o valor do uso, o valor intrínseco do metal e o valor de circulação tanto dos objetos quanto do dinheiro em si. Sendo assim, bens de natureza utilitária podiam transformar-se em valor intrínseco do metal e vice- 
versa. Esta visão pode ser constatada em obras como o tratado de João Sobrinho ${ }^{25}$.

A prata era quase toda de seu serviço pessoal, «minha prata com que me sirvo», e não era pouca. Entre os objetos: uma bacia grande de barbear, um jarro, um prato grande «e dois mais pequenos iguais e outros dois abaixo destes dois pratos iguais». Me parece que estes eram objetos de sua toilete pessoal, servindo provavelmente para o asseio das mãos e do rosto. Ao contrário dos pés, como veremos, estas partes mais «nobres» do corpo merecem metais condizentes com a sua «condição» e passíveis de serem compartilhados com visitantes de vários tipos, especialmente com os convivas à mesa. De fato, o hábito de lavar as mãos à mesa, utilizando-se jarros de prata oferecidos pelos escravos, parece ter sido comum na colônia, como demonstra Leila Algranti ${ }^{26}$.

Sabemos a importância deste tipo de asseio, desde pelo menos as clássicas obras de Norbert Elias, complementadas posteriormente por análises como as de Georges Vigarello e Daniel Roche ${ }^{27}$. Especialmente no século XVII, o asseio das mãos e do rosto ganhou o foco das atenções pessoais e sociais voltadas ao corpo, uma vez que os banhos de imersão e a nudez corporal passaram a ser vistos com crescente desconfiança, e a limpeza das partes «expostas» do corpo torna-se o locus preferencial de averiguação e confirmação de status e civilidade, como mostra igualmente Fernand Braudel ${ }^{28}$. Matos de Aguiar parece não ter aberto mão deste tipo de demonstração de boas maneiras e do conhecimento das regras de civilidade. Estando em Salvador, centro administrativo do Estado do Brasil, deve ter tido grande oportunidade de exercer essa convivialidade pessoal e social em meio a suas movimentadas atividades políticas, creditícias e religiosas. Mesmo homens que se encontravam em pleno sertão da América portuguesa, diante de situações difíceis, tentaram preservar, na medida do possível, embora nem sempre com muito êxito, certos parâmetros de comportamento, asseio e civilidade europeus, como mostra Laura de Mello e Souza ${ }^{29}$.

${ }^{25}$ Frei João Sobrinho, De Justitia Commutativa, Paris, Guy Marchant, 1496. Sobre os significados do dinheiro ver também: Craig Muldrew «"Hard food for Midas', Cash and its Social Value in Early Modern Englan», Past and Present, vol. 170, 2001, pp. 78-120.

${ }^{26}$ Leila Mezan Algranti, «Famílias e vida doméstica», in Laura de Mello e Souza (org.), História da vida privada no Brasil: cotidiano e vida privada na América portuguesa, São Paulo, Companhia das Letras, 1997, p. 126.

${ }^{27}$ Norbert Elias, A sociedade de corte, Lisboa, Estampa, 1987; Norbert Elias, O Processo Civilizador, Rio de Janeiro, Jorge Zahar, 1994; Georges Vigarello, O limpo e o sujo, São Paulo, Martins Fontes, 1996; e Daniel Roche, ob. cit.

${ }^{28}$ Fernand Braudel, Civilização material, economia e capitalismo, séculos XV-XVIII: as estruturas do cotidiano. São Paulo, Martins Fontes, 1995, p. 297. Segundo o autor, há um progressivo recuo dos banhos públicos entre os século XVI e XVII, impulsionado, tanto pela propagação da sífilis, quanto pela pregação moral reformista de católicos e calvinistas na Europa. p. 298.

${ }^{29}$ Laura de Mello e Souza, «Formas provisórias de existência: a vida cotidiana nos caminhos, nas fronteiras e nas fortificações» In Laura de Mello e Souza (org.). História da vida privada no 
$\mathrm{Na}$ estrutura do testamento de Matos de Aguiar, os pratos supostamente de asseio pessoal, fazem a transição para os objetos do serviço de mesa, sendo igualmente uma hipótese, que algum destes fizessem parte efetivamente deste serviço. Não parece ser por acaso, que objetos de higiene «mais nobres» sejam relatados junto aos de mesa, todos feitos do mesmo material igualmente nobre, uma vez que faziam parte deste universo a um só tempo público e privado da sociabilidade do período. Havia ainda, portanto, doze pratos de serviço de mesa, uma raridade para o universo geral dos territórios americanos, tanto na quantidade como no material de composição, especialmente se pensarmos, como mostra Leila Algranti, que na capitania de São Paulo seiscentista, por exemplo, reinavam absolutos os pratos de estanho ${ }^{30}$. Sua existência reforça o argumento acerca do investimento no recebimento de visitantes, como comentado acima. Além dos pratos constam ainda: duas tamboladeiras ${ }^{31}$ grandes, três salvas ${ }^{32} \mathrm{e}$ «duas tamboladeirinhas com seus pratinhos», as quais, como esclarece o testador, talvez temendo a ignorância local dos costumes correntes no reino, «servem vinho onde beber por elas». No caso das tamboladeiras de vinho, entretanto, estas não parecem ter sido tão raras, uma vez que aparecem em inventários das famílias paulistas discutidos por Algranti ${ }^{33}$. Encontramos ainda uma bandeja grande e outra menor, um talher ${ }^{34}$ de prata «com cinco peças», doze colheres e seis garfos. Somavam-se a essas peças, uma tijela grande com sua tampa, seis [conhetes] ${ }^{35}$ com suas tapadeiras, três facas com cabos de prata e um copo de beber água.

Quatro castiçais, igualmente de prata, garantiam a iluminação à noite, nas refeições e na casa de modo geral. Certamente um luxo para a época, como demonstra Daniel Roche para o caso francês, mesmo se levarmos em consideração, como afirma Leila Algranti, que diversos tipos de castiçais aparecem nos inventários coloniais desde o século $\mathrm{XVI}^{36}$. João de Matos aguardava ainda,

Brasil: cotidiano e vida privada na América portuguesa, São Paulo, Companhia das Letras, 1997, pp. 41- 81 .

${ }^{30}$ Leila Mezan Algranti, ob. cit., p. 122.

${ }^{31}$ Tamboladeira - recipiente utilizado para degustar, provar, servir vinho.

${ }^{32}$ Salva: «a peça de ouro, prata ou outra materia, sobre que se serve ao senhor o vaso em que há de beber. Fazer a salva ou tomar a salva antigamente era a cerimônia nos palácios dos príncipes.». Raphael Bluteau, ob. cit., vol. 7, p. 456.

${ }^{33}$ Leila Mezan Algranti, ob. cit., p. 128.

${ }^{34}$ Talher: peça de mesa redonda, ou quadrada, quase do feitio da salva, mas com quatro pés, e em cima galhetas de azeite e vinagre e outros vasos pequenos com adubos e etc» Raphael Bluteau, ob. cit., vol. 8, p. 26.

${ }^{35}$ Não foi possível identificar esse objeto ou corrigir a grafia. No dicionário de Raphael Bluteau aparece a palavra «cunhete» referindo-se a «barrilinho em que vem passas e figos». D. Rahpael Bluteau, ob. cit., vol 2, p. 638.

${ }^{36}$ Entre os séculos XVII e XVIII a escuridão ainda reina na França camponesa e mesmo nos centros urbanos predominam os candelabros de tipos mais comuns. Daniel Roche, ob. cit., p. 168. Roche atenta igualmente para a precariedade do predomínio das luminárias móveis, que deviam 
segundo declara, a chegada de um sofisticado talher vindo de Lisboa, pela carregação de Manuel Pires Quaresma, que havia custado mais de duzentos mil réis.

Todo este investimento no equipamento de mesa mostra como este tipo de convivialidade era central, não apenas um espaço de convivência, mas também de civilidade, de demonstração de status, além de ser locus privilegiado de debates e de práticas políticas. Isto significa dizer que parte dos recursos do testador havia sido investida em objetos de prata capazes de serem utilizados à mesa, ou seja, servindo às demandas da convivialidade seiscentista. Sua prataria de mesa indica ainda a possibilidade da manutenção de certos hábitos reinóis, como o consumo de vinho, em objetos específicos para isto, bem como os recipientes para azeite, vinagre e afins. Se Matos de Aguiar provou ao longo de sua vida as rudezas e os rigores da vivência e da alimentação dos sertões, descritas por Laura de Mello e Souza, parece que em sua velhice, recolhido em sua morada de casas da rua Direita em Salvador, havia conquistado um modo de vida que em nada, ou em pouca coisa, deixaria a desejar a seus conterrâneos ${ }^{37}$. Ainda assim, é preciso lembrar o alerta feito por Leila Algranti, de que os residentes em territórios americanos podiam amargar longas temporadas de espera pelos produtos vindos do reino e serem obrigados a pagar quantias consideráveis por estes mimos, verdadeiros itens de «necessidade» nesta «cultura das aparências» ${ }^{38}$.

Além dos objetos de asseio e de mesa, havia outros objetos pessoais de prata, os quais tinham para nossa personagem uma importância nada desprezível. São objetos pertencentes à vestimenta e ao aparato masculinos, todos ligados às necessidades da «performance» pública de poder e dignidade. Entre eles havia um espadim ${ }^{39}$, uma espada e a ferragem de seu boldrie $e^{40}$, armas que poucos tinham o direito de portar ou podiam aspirar possuírem, quer fosse no reino ou em ultramar. Dignidades estas que vinham provavelmente de seu estatuto de cavaleiro da Ordem de Cristo e de familiar do Santo Ofício.

De prata eram igualmente os acessórios de seu vestuário: botões de calção, fivelas de sapatos, botões de casacão, doze botões e colete e ainda um sinete ${ }^{41}$.

seguir os convivas pela casa. Para Fernand Braudel, a iluminação, das tochas e lanternas aos castiçais e lustres, é um luxo tardio nas casas da Europa. Fernand Braudel, ob. cit., p. 279. Sobre a iluminação colonial ver Leila Mezan Algranti, ob. cit., p. 130.

${ }^{37}$ Laura de Mello e Souza, ob. cit.

${ }^{38}$ Leila Mezan Algranti, ob. cit., p. 132. Sobre o conceito de «cultura das aparências» ver Norbert Elias, ob. cit. e Daniel Roche, ob. cit.

${ }^{39}$ Espadim: «espada de folha curta e de pequenas guarnições». Raphael Bluteau, ob. cit., vol. 3, p. 255. «Pequena espada de lâmina mais delgada que a comum. Dicionário enciclopédico ilustrado Larousse, São Paulo, Larousse do Brasil, 2007, p. 415.

${ }^{40}$ Boldrié: «É uma correia, que cinge pela cintura, e tem dependurados outros bocados de correias, que tem uns anéis, em que se mete a espada». D. Raphael Bluteau, ob. cit., vol. 2, p. 143.

${ }^{41}$ Sinete: «com que se selam as cartas» Raphael Bluteau, ob. cit., vol. 7, p. 656. «selo ou carimbo, gravado em relevo ou embaixo-relevo com as armas ou as iniciais de quem o usa». Dicionário enciclopédico ilustrado ..., p. 937. 
Como argumenta Daniel Roche, no século XVII, seguir a moda significava o respeito e a obediência à tradição, aos usos e às maneiras de agir. Neste sentido, $o$ vestuário comunicava a posição do indivíduo em relação à comunidade, sua idade, gênero, estado, profissão e estatuto social. Designava igualmente, os estigmas, as minorias e as relações de poder, sem excluírem, no entanto, as «usurpações de sinais», as quais podiam confundir e subverter os sinais da representação social pelo vestuário ${ }^{42}$. Podemos dizer, que nesta «cultura da aparência», que privilegiava a exterioridade passível de julgamento coletivo, a profusão de acessórios de prata de Matos de Aguiar, proviam-no com as necessárias marcas de poder e dignidade buscadas pelos homens bons do período.

Em ouro, João de Matos possuía um cordão com o hábito ${ }^{43}$ de Cristo e outro com o hábito de familiar do Santo Ofício, juntamente com um hábito de Cristo esmaltado, bem como o de familiar, e um hábito pequeno que vinha com ele. A importância dos hábitos pode ser avaliada na riqueza com que João de Matos os conservava, pois guardava seus hábitos em um saco de damasco carmesim ${ }^{44}$. Mereciam, por conseguinte, o cuidado de serem guardados em bolsas de tecido nobre, o que na época significava material trabalhado, como era o caso dos tecidos adamascados. Este saco, como veremos adiante, foi um dos legados deixados às filhas de um compadre seu.

Neste momento, é interessante um comentário. Para seu enterramento, Matos de Aguiar, que era irmão terceiro da ordem de São Francisco, pede que seu corpo seja amortalhado com o hábito «de meu padre São Francisco» e, por cima dele, seja colocado o manto da Ordem de Cristo, como afirma era o costume de então. Desta maneira, unia a dupla demanda seiscentista, de um lado a devoção pessoal a São Francisco e de outro a demonstração pública de seu estatuto social. Ou seja, para dentro a devoção franciscana e para fora a ostentação do manto da Ordem de Cristo. O ouro dos seus respectivos hábitos, entretanto, como vimos, não acompanhou seu corpo à sepultura, uma vez que devia ser vendido. Tal situação não deixa de demonstrar a curiosa ambiguidade destes símbolos que podiam, portanto, ser expostos a práticas de venalidade. Vale lembrar igualmente, que os hábitos também não vão para o sobrinho, que recebe, como vimos, a valia de seus serviços ao rei para buscar mercês e provavelmente o próprio hábito da dita ordem. Neste caso, e seria preciso o estudo de outros casos para podermos levan-

${ }^{42}$ Daniel Roche, ob. cit.,pp. 257-259. Para o caso da América portuguesa ver Silvia Hunold Lara, Fragmentos setecentistas: escravidão, cultura e poder na América portuguesa, São Paulo, Companhia das Letras, 2007.

${ }^{43}$ Hábito: «se chama a insignia das ordens de Cristo, Santiago e Avis, e a de familiar do santo ofício, a dos maltezes se chama somente malta.». Raphael Bluteau, ob.cit., vol. 4, p. 5.

${ }^{44}$ Damasco: «seda de lavores, entre tafetá e raso, assim chamado, porque a invenção veio da cidade de Damasco. Há Damascos de seda de Castela, e Itália, e Damasco da Índia ordinários; Damasco tecido com ouro e prata, Damasco carmezim, Damascos, ditos grandes». Raphael Bluteau, vol. 3, p. 6 . 
tar hipóteses mais consequentes. Os objetos de uso relativos aos hábitos mostram-se individuais, ainda que a conquista dos mesmos fosse, em muitos casos, empreitada familiar. Seja como for, mais vale que a prataria seja empregada no financiamento dos sufrágios pela sua alma. Cumpre-se deste modo, ainda, um certo despojamento do corpo, que era necessário àqueles que partiam da vida presente.

Despojamento este que não encontramos nos objetos de sua moradia, enquanto Matos de Aguiar habitou o mundo da matéria. Para Daniel Roche, no caso europeu, a evolução da intimidade e da sociabilidade ditou as escolhas do mobiliário numa progressiva individualização e especialização das peças que coincidia com a maior compartimentalização das casas e autorizava maior racionalidade na maneira de organizar os objetos ${ }^{45}$. Sendo assim, partiu-se de objetos mais escassos e de menor especialização de uso para uma miríade de bens que respondiam a necessidades e demandas cada vez mais sofisticadas e específicas no século XVIII.

Segundo Fernand Braudel, na Europa do século XVII, especialmente na França, na Inglaterra e nos Países Baixos católicos, a decoração da casa «sacrifica tudo à mundaneidade, ao significado social. A sala de visitas tornou-se imensa, de teto muito alto, mais aberta ao exterior, intencionalmente solene, com uma sobrecarga de ornamentos, de esculturas, de móveis de aparato exibindo peças de prata igualmente aparatosas $»^{46}$. O luxo do século XVII, ainda ignora, entretanto, para Braudel, as comodidades e a intimidade. O luxo de João de Matos, desfrutado em terras ultramarinas, parece investir tanto na convivialidade mundana quanto no repouso, segurança e conforto pessoal. Este deve ser visto, entretanto, com cautela, pois não deixa de estar marcado pelos aparatos de limpeza e ostentação específicos da sociabilidade cortesã, como demonstram os objetos de asseio pessoal mencionados.

Para o caso francês, Daniel Roche aponta que a mobília torna-se, ao longo da Época Moderna, o meio de expressar a riqueza, mesmo entre os pobres, os quais de modo geral, tinham que se satisfazer com um mobiliário mais tosco ${ }^{47}$. Ao menos desde o século XVI, houve um investimento cada vez maior em variedade, sofisticação e elaboração das peças e materiais, se comparados com períodos anteriores. Isabel dos Guimarães Sá mostra como o consumo de objetos de luxo, nas cortes portuguesas, encontrava-se amplamente difundido entre os séculos XV e XVI, havendo uma marcante preferência pela orientalia ${ }^{48}$. Como demonstra Roche, nesta civilização das aparências, na vida comum da maioria, os preceitos da distinção atingem em primeiro lugar as vestimentas, o traje, e,

\footnotetext{
${ }^{45}$ Daniel Roche, ob. cit., p. 253.

${ }^{46}$ Fernand Braudel, ob. cit., p. 277.

${ }^{47}$ Daniel Roche, ob. cit., p. 240.

${ }^{48}$ Isabel dos Guimarães Sá, ob. cit.
} 
posteriormente, os móveis, que de início eram mais ligados à utilidade e disponibilidade de recursos ${ }^{49}$. João de Matos encontra-se entre os homens de cabedais, materiais e simbólicos, que podem e, mais do que isto, têm por obrigação expor seu status, tanto por meio de suas vestimentas e armas, quanto por meio de sua casa, mobiliário e alfaias domésticas.

Matos de Aguiar deixou para sua afilhada baiana, filha de seu compadre Manuel Pires Rebouça, e suas irmãs, além de recursos para o seu dote, parte importante do mobiliário de sua casa e algumas alfaias ainda novas e a partir deles podemos fazer alguns comentários sobre sua posse de mobiliário doméstico. Se compararmos seu mobiliário com aquele encontrado por Leila Mezan Algranti para as moradias coloniais mais corriqueiras, podemos afirmar que se tratava de um mobiliário sofisticado e complexo para os padrões do período ${ }^{50}$. Nos relatos encontrados nos inventários paulistas, por exemplo, o mobiliário doméstico reduz-se, segundo Algranti, a poucas cadeiras, uma ou duas mesas com bancos e algumas caixas ou baús. Como afirma a própria autora, a exceção a esta regra parece ter sido as casas da zona açucareira e, especialmente, aquelas pertencentes a autoridades, como capitães-mores, ou ricos fazendeiros. Nesse sentido, o mobiliário de Matos de Aguiar parece ilustrar bem essa exceção. Devemos acrescentar, entretanto, que o mobiliário do testador seria provavelmente igualmente raro em terras reinóis, uma vez que o século XVII europeu ainda presenciava um mobiliário mais simples, segundo Daniel Roche ${ }^{51}$.

Nosso testador deixou duas dúzias de cadeiras, que talvez formassem um conjunto de mesa, dois bofetes ${ }^{52}$ e um tamborete ${ }^{53}$ («de que me sirvo»). Estes móveis de Matos de Aguiar merecem algum detalhamento. Comecemos pelo objeto que servia tanto à mesa quanto à convivialidade em geral: as cadeiras . Segundo Daniel Roche, as cadeiras teriam sido majoritariamente ignoradas durante a Idade Média, na medida em que eram reservadas aos reis e às imagens religiosas, sendo que as pessoas comuns sentavam-se em qualquer lugar, como no chão, em arcas ou em bancos, caso houvesse ${ }^{54}$. Teria sido no século XV que elas apareceram mais significativamente dentro de universos propriamente domésticos, seguindo as funções de escrita, conversação ou refeição. Entre os séculos XVI e XVIII, segundo Roche, as cadeiras teriam se aproximado da mesa e passado a dominar o espaço social. Neste caso, os assentos fazem parte do convívio social e ajudam a discernir hierarquicamente os indivíduos, como no caso

\footnotetext{
${ }^{49}$ Daniel Roche, ob. cit., 243.

${ }^{50}$ Leila Mezan Algranti, ob. cit., p. 105.

${ }^{51}$ Daniel Roche, ob. cit.

${ }^{52}$ Bofete [bofète]: «em que se escreve ou em que se conta dinheiro». Raphael Bluteau, $o b$. cit., vol. 2, p. 141.

${ }^{53}$ Tamborete [raso]: «assento sem braços, nem espaldar, chama-se assim porque tem feição de um pequeno tambor» Raphael Bluteau, ob. cit., vol. 8, p. 34.

${ }^{54}$ Daniel Roche, ob. cit., p. 232.
} 
da corte real, por exemplo, mas não só. As cadeiras significaram, ao mesmo tempo, a individuação, em oposição aos bancos, e o descanso sustentado por uma postura ereta ${ }^{55}$. Segundo Leila Algranti, bancos, tamboretes e bofetes, quase sempre rústicos, eram frequentemente utilizados para o serviço ou o descanso na América portuguesa no período ${ }^{56}$. Sentar-se no chão ou em esteiras, entretanto, parece ter sido comum, e mesmo ter se mantido um costume detectado por viajantes até o século XIX ${ }^{57}$. Este, entretanto, não parece ser o caso deste homem de elite, já idoso, residente em Salvador. João de Matos possuía conjuntos consideráveis de cadeiras, a ponto de qualificá-las por tipo e antiguidade e de distribuílas segundo critérios de estratificação social.

Como mostra Daniel Roche, no século XVII, e muito além dele, o mobiliário dos interiores tinha ainda um grau relativo de especialização, podendo ser utilizado para diversas funções, reorganizado ou reaproveitado ${ }^{58}$. Desta forma, um cofre, por exemplo, podia servir de mesa ou por vezes de assento. Neste sentido, é possível levantar a hipótese de que um (ou ambos) bofetes listados por João de Matos, fosse utilizado como mesa de jantar, na medida em que seu testamento não menciona nenhuma mesa, mesmo tendo listado um número considerável de cadeiras e um complexo serviço de mesa. Outra hipótese, também viável, é a de que o serviço de mesa de prata de João de Matos pudesse ser parte de uma coleção voltada ao luxo e à ostentação, como sugere o caso da pesquisa de Cristina Osswald acerca do colecionismo presente nas ordens religiosas ${ }^{59}$. Neste caso, o serviço não seria necessariamente utilizado em refeições e na promoção da sociabilidade. $\mathrm{O}$ número de cadeiras existentes em sua casa apontam, entretanto, para um investimento no recebimento de pessoas, fosse esta atividade ligada à convivialidade social, aos negócios ou ambos. É possível, por conseguinte, que tivessem essa dupla função.

Entre os objetos deixados encontrava-se um leito ${ }^{60}$ com seus três colchões, um cobertor de cochonilha ${ }^{61}$ e dois lençóis novos rendados («que até aqui não

${ }^{55}$ Daniel Roche, ob. cit., p. 252.

${ }^{56}$ Leila Mezan Algranti, ob. cit., p. 107.

${ }^{57}$ Ver Leila Mezan Algranti, ob. cit., p. 123.

${ }^{58}$ Daniel Roche, ob. cit., p. 226.

${ }^{59}$ Cristina Osswald, «Aspectos de decoração e colecionismo entre as ordens religiosas em Portugal na Época Moderna (séculos XVI-XVIII)», São Paulo, palestra ministrada na Cátedra Jaime Cortesão - USP, 2009.

${ }^{60}$ Leito: «consta de um catre com quatro colunas, ou pilares altos, e táboas sobre que se põe a cama, arma-se com cortinas». Raphael Bluteau, ob. cit., vol. 5, p. 74.

${ }^{61}$ Cochonilha: «consta pois que cochonilha é um pequeno inseto, quase da feição de persevejo, que se cria em muitas castas de árvore das Índias de Castela. Os índios o colhem e o transpõem em uma espécie de figueira da terra, cujo fruto está cheio de um suco vermelho, como sangue. (...) Há muitas castas de Cochonilha, a que chamam Mestec, ou Mesteque, vem do Peru, do México, e de outros lugares da América, por Cadiz. Tingem com ela panos de escarlata». Raphael Bluteau, ob. cit., vol. 2, p. 356. 
usei deles»). A complexidade e o requinte, tanto de materiais como de peças, do conjunto formado pelo leito e seus aparatos parece contrastar com a simplicidade que predomina normalmente nas regiões coloniais observadas por Leila Algranti, onde, segundo a autora, as camas conviveram até o século XIX com redes, catres e jiraus ${ }^{62}$.

No caso europeu, Daniel Roche ressalta a importância e centralidade atribuída à cama nos domicílios, como fonte de proteção e isolamento, já no século XVII. Estas foram progressivamente elevadas do chão e ganharam estruturas protetoras, sendo seu maior ou menor luxo e riqueza representados igualmente pelos equipamentos acumulados, como travesseiros, lençóis e cobertas ${ }^{63}$. Como demonstra Roche para o caso francês, se a cama, a partir do século XVII, encontra-se disseminada pelos domicílios dos ricos e dos pobres, a roupa de cama marcava as diferenças, dependendo de sua variedade e qualidade ${ }^{64}$. O número de colchões, o cobertor, possivelmente adquirido em rotas comerciais que envolviam as «Índias de Castela», e os lençóis rendados dão sinal do luxo ao qual seu dono, neste caso, se permitia.

A cama era um elemento tão importante para um jovem casal, por exemplo, que representava grande investimento financeiro. Segundo a pesquisa de Roche, para a cidade de Bordeaux da década de 1670, um quinto dos dotes de casamento da época não cobriam o seu custo, tendo o leito, em muitos casos, um espaço considerável na elaboração e negociação dos contratos de casamento ${ }^{65}$. Devemos lembrar, como faz o mencionado autor, que a cama, até o século XVII, não é somente um espaço de descanso, mas também um local de recebimento de visitas, ao menos na Europa. No caso do leito descrito por Matos de Aguiar, em seu testamento, parece inequívoco que tratava-se da cama de um indivíduo com preponderância social.

Além do leito, a afilhada e suas irmãs ficariam também com quatro caixas de vinhático, espécie de madeira originária do Brasil ${ }^{66}$. Segundo Daniel Roche, a arrumação dos pertences seguiu igualmente uma evolução e desenvolvimento, marcado pela relação entre a maior especialização, variedade e sofisticação dos objetos, de um lado, e seu papel na fixação das hierarquias sociais de outro. Para o autor, o uso da arca, entre os séculos XVII e XVIII, sofreu um recuo conside-

${ }^{62}$ Leila Mezan Algranti, ob. cit., p. 107. Jirau significa qualquer armação de madeira em forma de estrado ou palanquete ou «cama de varas». Aurélio Buarque de Holanda Ferreira, Novo dicionario da lingua portuguesa, Rio de Janeiro, Nova Fronteira, 1975, p. 807.

${ }^{63}$ Daniel Roche, ob. cit., pp. 233-234. Sobre a importância do leito ver também Orest Ranum, «Os refúgios da intimidade», in Roger Chartier (org.) História da vida privada 3: da Renascença ao século das Luzes, São Paulo, Companhia das Letras, 2009, p. 221.

${ }^{64}$ Daniel Roche, ob. cit., p. 244.

${ }^{65}$ Daniel Roche, ob. cit., p. 245.

${ }^{66}$ Vinhático: «denominação comum a algumas árvores brasileiras da família das leguminosas, ornamentais, que fornecem madeira amarelada, muito usada em marcenaria» in Dicionário enciclopédico ilustrado Larousse..., p. 1052. 
rável em todos os níveis sociais, o que para o mesmo significa um recuo do próprio modo de vida rural, marcado pela mobilidade e pela polivalência funcional ${ }^{67}$. Segundo o autor, nos locais onde encontramos maior divisão e especialização do espaço, as arcas foram sendo relegadas à cozinha, às despensas e aos banheiros. É bastante provável que as caixas de vinhático deixadas por Matos de Aguiar a sua afilhada fossem trabalhadas e sofisticadas o suficiente para fazerem parte do futuro enxoval de uma família de elite, como sugere a descrição feita pelo dicionarista D. Raphael Bluteau, reproduzida em nota, ao contrário do baú deixado a um seu escravo, como veremos.

Entre os bens destinados à afilhada encontramos ainda um objeto característico do transporte e da dignidade das elites em terras ultramarinas: uma rede ${ }^{68}$. Esta era branca e azul, «nova», como qualifica o testador, e possuía seu pau e tornos de marfim, além de forquilhas dos escravos que a carregavam. De fato, o costume de se fazer transportar por escravos em redes, caracterizado pelo dicionarista D. Raphael Bluteau para o caso indiano no século XVIII, era igualmente verdadeiro para os territórios americanos e já era verificado por Ambrósio Fernandes Brandão para o caso das mulheres no nordeste no início do século XVI ${ }^{69}$.

O marfim, do pau e tornos da rede, parece ser um dos poucos materiais orientais (ou africanos) que encontramos entre os pertences de Matos de Aguiar. Difícil saber se se trataria de uma rede trazida do oriente, e, neste caso, o mais interessante, como ela teria chegado às mãos de Matos de Aguiar, ou se teria sido tecida já na América, tendo apenas seus paus e tornos vindo do oriente. Seja como for, é interessante notar o uso de materiais não-nativos, apontando talvez para um circuito comercial mais alargado e sofisticado. Isto é, mesmo sendo a rede um instrumento conhecido e largamente utilizado pelos povos nativos da América, ao ser utilizada por um homem bom do século XVII, ela aparece equipada com materiais que lhe conferem um certo exotismo e prestígio, sendo importante lembrarmos do gosto pela orientalia, detectado para as cortes portuguesas e que, provavelmente, se espalhou por circuitos sociais mais alargados nos períodos seguintes. Se pensarmos que a Bahia era então um importantíssimo entreposto da carreira da Índia no período e também das rotas africanas, não seria de se espantar se fosse, de fato, um objeto vindo de longínguas possessões portuguesas $^{70}$. Além da rede, a afilhada deveria ficar com o mencionado saco de

${ }^{67}$ Daniel Roche, ob. cit., p. 248.

${ }^{68}$ Rede: 1) «tecido grande de algodão, em que o gentio do Brasil, e outro das Índias Ocidentais dorme, pendurando-o do tronco de uma árvore a outro»; 2) «Rede, em que na Índia, e outras partes, os negros, ou escravos, que chamam carregadores, levam gente». Raphael Bluteau, ob.cit., vol. 7, p. 171 .

${ }^{69}$ Ambrósio Fernandes Brandão, Diálogos das grandezas do Brasil (1618), Rio de Janeiro, Oficina Industrial Gráfica, 1930, p. 264 Apud Leila Mezan Algranti, ob. cit., p. 116.

${ }^{70}$ Sobre o papel da Bahia na carreira da Índia ver José Roberto do Amaral Lapa, A Bahia e a carreira da Índia, São Paulo, Comp. Ed. Nacional, 1968. 
damasco carmesim, que guardava seu hábito de Cristo, tecido nobilíssimo, que envolvera suas insignias de cavaleiro e que, daquele tempo em diante, passaria a guardar seus pertences de senhora.

Para a afilhada ficavam ainda seus objetos de culto pessoal, nomeadamente um oratório ${ }^{71}$ com dois crucifixos e quatro painéis que tinha em sua escrivaninha, segundo suas palavras. Como mostra Leila Algranti, os oratórios particulares, sinais de uma «vida íntima em ascensão», faziam cada vez mais parte da vida doméstica e tornaram-se ainda mais comuns com o desenrolar do século XVIII ${ }^{72}$. Segundo Luiz Mott, os oratórios serviam como uma espécie de «relicário» doméstico, onde se podiam conservar imagens de santos; relíquias, como o Santo Lenho; livros de oração e catecismos ${ }^{73}$. Algumas famílias mais abastadas do nordeste açucareiro, podiam chegar a ter o chamado quarto dos santos, onde ficavam depositadas as imagens dos santos e santas de sua devoção. Para Leila Algranti, todo esse aparato religioso «está relacionado ao costume doméstico de se fazerem as orações diárias em casa, cumprindo os rituais e até as horas canônicas ${ }^{74}$. No caso de Mattos de Aguiar, possuímos apenas a informação dos dois crucifixos, possivelmente uma predileção sua como irmão terceiro franciscano, sem ter idéia do conteúdo dos quatro painéis. Ainda assim, devemos notar que o oratório deveria ser de tamanho considerável, pensando-se nos exemplos de época que chegaram até nós, e repousava sobre a sua escrivaninha, como descreve o testador, dominando sua visão frontal nos momentos de escrita e contabilidade ${ }^{75}$.

Deixava, portanto, à filha de seu compadre e suas irmãs, os objetos dignos de habitarem uma casa senhorial: alfaias novas rendadas, bem cuidadas e de materiais nobres; leito guarnecido com colchões; considerável número de cadeiras; além de objetos de uso religioso, igualmente indispensáveis às habitações de pessoas de alguma qualidade. Como reafirma o testemunho de Alcantara Machado, lembrado por Leila Algranti, era na «baixela e nas alfaias de cama e mesa que a gente apotentada faz timbre em ostentar a sua opulência» e Matos de Aguiar parece não ter sido excessão a essa regra ${ }^{76}$. Os objetos deixados à afilha-

${ }^{71}$ Oratório: «(...) há oratórios que se cavam na parede, ou se fazem a moda de armários, com suas portas; tem dentro um Cristo crucificado, e outras imagens, que convidam a orar» Raphael Bluteau, ob. cit., vol. 6, p. 100.

${ }^{72}$ Leila Mezan Algranti, ob. cit., p. 103.

${ }^{73}$ Luiz Mott, «Cotidiano e vivência religiosa: entre a capela e o calundu», in Laura de Mello e Souza, História da vida privada no Brasil: cotidiano e vida privada na América portuguesa, São Paulo, Companhia das Letras, 1997, pp. 166 e 167.

${ }^{74}$ Leila Mezan Algranti, ob. cit., p. 130.

${ }^{75}$ Escrivaninha: «caixa em que se traz o necessário para escrever, como penas, tinta, canivete.» Raphael Bluteau, ob. cit., p. 228, vol. 3.

76 A. de Alcantara Machado, Vida e morte do bandeirante, São Paulo, Martins Fontes, Instituto Nacional do Livro, 1972, p. 87 apud Leila Mezan Algranti, ob. cit., p. 122. 
da guardam ainda uma clara relação com aqueles que normalmente se agrupavam nos enxovais e que, muitas vezes, faziam parte dos dotes atribuídos pelas famílias às filhas e parentas (e mesmo por instituições de caridade a moças órfãs) em idade de se casarem.

Em termos de mobiliário devemos acrescentar ainda mais dois contadores que João de Matos possuía e que deixava para a mesa dos irmãos da Misericórdia, seus testamenteiros, onde constavam os papéis de suas dívidas ativas e os demais necessários para a clareza de suas últimas vontades, como esclarece o próprio testador. Podemos arriscar que este seria o conjunto de seus móveis «profissionais», ligados especialmente às demandas de registro de suas funções de financista. Arriscando mais ainda, podemos pensar que talvez ficassem próximos à escrivaninha com oratório, expondo suas atividades financeiras ao olhar das imagens religiosas. Ainda que a existência de um contador não seja incomum nos domicílios de senhores de engenho ou mercadores, o fato de haverem dois pode indicar a intensidade de suas atividades de registro pessoal e financeiro e o investimento feito nestas mesmas atividades.

Entre as possíveis ausências, encontram-se os livros. Não há menção a eles, a não ser seu livro de contas. Difícil avaliarmos se Matos de Aguiar de fato não os possuía, se já os havia, por exemplo, distribuído entre seus sobrinhos ou pessoas de sua relação ou se não os considerava dignos de serem objeto de legado. Ficaremos com esta indagação, uma vez que não encontramos sequer menção a livros de devoção, comuns ao período. Não há menção igualmente a livros de contabilidade -nem «livros de razão», nem «borradores»- apenas «papéis», designados genericamente e guardados em seus contadores. $\mathrm{O}$ «livro de contas», mencionado por Matos de Aguiar, estava sendo elaborado, segundo ele mesmo, para acompanhamento do testamento.

Um objeto que se tornou uma febre na Europa do século XVII encontra-se igualmente ausente: o relógio. É difícil avaliar sua presença ou raridade no reino, e principalmente no Ultramar. Entretanto, é interessante notar que a montagem de relógios aparece em um dos mais populares manuais pedagógicos portugueses do século XVII, intitulado Tesouro dos prudentes, o qual parece ter tido grande circulação no norte de Portugal ${ }^{77}$.

Em seu testamento, Matos de Aguiar revelou possuir, dentro de sua casa, um considerável volume de fazendas variadas que deveriam ser vendidas para ajuda de custo dos seus legados, como tecidos de linho e bertanhas, metais entre cobre e ferro e fio de vela, entre outras coisas. Em seu caso, é difícil saber se estas fazendas lhe serviam para mercadear propriamente, incluindo, neste caso, as trocas relativas à sua atividade creditícia, ou se deviam abastecer seus currais

${ }^{77}$ Para saber mais sobre a obra de Gaspar Cardoso de Sequeira, Tesouro dos prudentes..., Coimbra, oficina de Nicolau Carvalho, 1612 ver A. A. Marques de Almeida. Aritmética como descrição do real (1519-1679), Lisboa, CNCDP - Casa da Moeda, 1994. 
e fazendas de açúcar, sendo provavelmente verdadeiras as duas hipóteses. De qualquer modo, indicam que provavelmente havia em sua casa um espaço onde mercadorias podiam ser estocadas, algo comum não somente entre os mercadores do período como também em boa parte dos sobrados em geral $^{78}$.

Por fim, para os escravos de seu serviço de casa, deixava, além das alforrias, atitude comum nas elites ultramarinas, as roupas do seu corpo, os objetos do cuidado corporal diário e os de cozinha mais cotidianos. Este era, afinal, o seu locus por excelência. Os escravos e escravas ficavam, portanto, com o «fato» de seu serviço. Ficavam principalmente com as roupas de dentro, as mais íntimas, aquelas que, em contato direto, envolvem o corpo e que não possuem em si, a princípio, marcas de distinção social, muito pelo contrário, estão muito mais próximas às noções de corporalidade, de baixeza e de corruptibilidade do mundo material.

Essas roupas íntimas -camisas e «algum vestido meu [seu]»- deviam ser divididas pela escrava, de nome Cecília, entre suas duas filhas e filho, todos mulatos, sem distinção ou especialização, portanto, de gênero. Os escravos João e Batista ganhavam cada um uma casaca, possivelmente as únicas peças de vestimenta exterior que recebem. Os tecidos parecem ser sempre pouco nobres e não trabalhados, contrastando com a riqueza das alfaias designadas à afilhada e mais aparatos «exteriores», como os hábitos de cavaleiro, sendo que a única menção explícita a sua qualidade indicava calções e vestidos de baeta.

A negra Cecília ganhava ainda os apetrechos de cozinha. Entre eles, dois caldeirões de cobre, um tacho, bacias, seringas e almofariz ${ }^{79}$, sem discriminação de sua quantidade ou material. Por mais que estes objetos fossem, de fato, de algum valor e se diferenciassem, por exemplo, dos objetos de cerâmica ou cestaria presentes, em muitos casos, nos domicílios coloniais, ainda assim distavam da nobreza de sua prataria, que foi vendida para custear seu enterramento, e das alfaias designadas às filhas do compadre. Ainda que se refira aos escravos com grande afetividade, como havia feito igualmente no caso do compadre, as hierarquias afetivas parecem estar em discrepância com as hierarquias dos bens, as quais deveriam ser regidas, como dissemos no início, segundo as hierarquias sociais e a assimetria dos poderes. Encontramos, portanto, uma clara diferenciação e hierarquização entre os objetos de cozinha, por exemplo, e aqueles destinados ao descanso, como o leito; ao asseio, como as bacias de prata; e à convivialidade, como os talheres e as cadeiras.

Cecília ficou também com três cadeiras, as quais o testador qualificou como «antigas» e mais três cadeiras roxas. Recebeu ainda uma bacia de arame de lavar os pés. Mais uma vez é possível realizar uma espécie de paralelo entre os obje-

${ }^{78}$ Daniel Roche, ob. cit., p. 117.

${ }^{79}$ Almofariz: «(...) é um vaso de metal em que pisam vários ingredientes». Raphael Bluteau, ob. cit., vol. 1, p. 274. 
tos e as partes do corpo, de um lado, e a sua consequente hierarquização, de outro. A tina de barbear e os jarros, provavelmente feitos para asseio do rosto e das mãos, os quais vão à mesa e, portanto, são destinados à convivialidade «honrada», eram de prata, ao passo que a bacia de lavar os pés era de arame e, por isso, podia constar entre bens deixados para a escrava. Devemos notar, entretanto, que a mesma escrava ficava ainda com todo o resto que fosse do serviço da casa e que não estivesse incluído na prataria e nem nos objetos de enxoval deixados à afilhada. Por ser o testamento um instrumento público, talvez Matos de Aguiar tenha sido cauteloso na distribuição igualmente pública de seus bens. Sem mais especificações, não é possível saber, nesse caso, se o testador manteve, com relação ao restante de seus bens do serviço, a lógica de articular objetos, partes do corpo e da casa e hierarquias sociais ou se deixou o afeto, em silêncio, inverter algumas destas hierarquizações.

O escravo Batista recebeu igualmente um baú. Como podemos notar pela exposição de Leila Algranti, os baús eram peças comuns entre a população da colônia, mesmo nos inventários mais pobres, possivelmente devido a sua grande mobilidade, como aponta a autora, e também a suas diversas possibilidades de uso, como demonstrou Daniel Roche ${ }^{80}$. De acordo com este autor, os baús e as arcas predominavam no campo europeu na Época Moderna e pertenciam ainda ao universo da precária especialização dos móveis. Tratavam-se de móveis rústicos, baixos e capazes de acolher indistintamente objetos de diferentes materiais e funções ${ }^{81}$. Isto acentua igualmente a sua função como objeto ligado à mobilidade, tantas vezes acionada no universo colonial ${ }^{82}$. Não é de se espantar, por conseguinte, que este baú não tenha sido incluído entre os móveis deixados às filhas de seu compadre.

João de Matos de Aguiar era um homem de grandes cabedais e que teve acesso a boa parte dos objetos pertinentes às marcas e aos sinais de distinção disponíveis aos homens bons de seu tempo. Ao morrer, fez questão de fazer uso de seus bens de forma a contemplar necessidades celestiais e terrenas. Desta forma, distribuiu sua fortuna respeitando o diversificado tempo das coisas materiais, buscando, na medida do possível, aproximar o que era da temporalidade das almas e aquilo que era devido ao serviço e às funções da inconstância terrena. Respeitou também a complexa arquitetura que ordenava e entrelaçava as qualidades dos bens materiais às qualidades dos corpos, e suas partes; das pessoas e suas posições sociais. Procurou, por fim, a um só tempo respeitar os ditames de sua consciência espiritual e social «barrocas».

\footnotetext{
${ }^{80}$ Leila Mezan Algranti, ob. cit., p. 108; e Daniel Roche, ob. cit., p. 235.

${ }^{81}$ Daniel Roche, ob. cit., p. 235.

${ }^{82}$ Leila Mezan Algranti, ob. cit.; e Laura de Mello e Souza, ob. cit.
} 